\title{
Endogenous economic policy and the structure of production: Theory and evidence*t
}

\author{
Kwok Tong Soo \\ London School of Economics
}

September 23, 2003

\begin{abstract}
This paper develops and tests a model of electoral competition and campaign contributions. We extend the standard model to consider the implications for factor mobility and hence the structure of production. The model makes two main predictions. First, countries with more capital stock tend to implement more pro-capital policies. Second, countries with more pro-capital policies tend to specialise in capital-intensive goods. These predictions of the model are confirmed using data on cross-state differences in policies and economic outcomes in India.
\end{abstract}

\section{Introduction}

Economics meets politics in the sphere of economic policy-making. Economic analysis, while stressing the importance of the invisible hand of market forces in determining economic outcomes, must also take into account the impact of the visible hand of government policies in the economy. But causality also runs the other way; economic policies are determined not only by political factors, but also by present and expected economic conditions. The rapidly growing field of political economy stresses the two-way relationship between politics and economics.

But while there have been many theories on the two-way relationship between politics and economics (see Persson and Tabellini (1999) for a survey), there is much more limited discussion in the literature on how these endogenously determined policies impact on the economy. Empirical testing of such models is also in its infancy; Goldberg and Maggi (1999) and Gawande and

\footnotetext{
*Preliminary; comments welcome.

${ }^{\dagger}$ I am very grateful to Steve Redding for many helpful discussions, and Robin Burgess for access to data.

${ }^{\ddagger}$ Correspondence: Centre for Economic Performance, London School of Economics, Houghton Street, London WC2A 2AE, United Kingdom. Email: k.t.soo@lse.ac.uk
} 
Bandyopadhyay (2000) are early examples which test the Grossman and Helpman (1994) "Protection for sale" model of endogenous tariff formation in a world of special interest groups. The present paper seeks to develop and test econometrically a model of endogenous policy formation and its implications for the structure of production in an economy. One can think of this paper as forming a link between the political economy literature which concentrates on how policies are determined, and the wider literature which takes policies as given and considers its impact for economic outcomes.

Our model is based on a simplified version of Grossman and Helpman (1996), which we incorporate into a factor endowments model of international trade with capital mobility. We first show how special interest groups (owners of capital) can influence policy through campaign contributions, even when they do not play a major role in the actual voting process. Government policy is modelled as a public good. We find that the country with more capital will implement more pro-capital policies, and thus in the presence of capital mobility, be able to attract even more capital into the country. Comparative advantage matters for current patterns of trade, but initial absolute endowments of capital matters for future patterns of production. This can lead either to the reinforcement or reversal of initial comparative advantage.

There have of course been previous models on the impact of endogenous policy formation on capital mobility; examples include Persson and Tabellini (1992) and Haufler (1997). Several features distinguish our model from previous models. First, it is based on a two-good, two-factor model of international trade; this allows us to derive some results on the impact of factor mobility on the structure of production. Second, policies in our model have a public good property; the cost of enacting a pro-capital policy is the same regardless of the amount of capital in the economy. Finally and fairly crucially for our results, unlike Persson and Tabellini (1992) who model governments as being interested in the welfare of voters with the same income level as themselves, and Haufler (1997) whose government maximises a weighted average of capital and labour welfare, the government in our model maximises the share of votes that they get in an election. In the process of doing so, it has to compete with a rival party using a combination of campaign contributions and policies, but this results in the capital lobby being able to exploit this rivalry to maximise its own welfare at the expense of the political parties.

On the empirical side, we then test for the impact of capital endowments on economic policy using state-level data on India between 1959 and 1997. We use Besley and Burgess' (2002) labour regulation indicator as a measure of whether the policy stance of a state is pro-capital or pro-labour. Our empirical strategy uses instrumental-variables methods to overcome the endogeneity problem. Even when we control for numerous other factors, capital endowments have a strong impact on policy. More precisely, the greater the endowment of capital in a state, the more pro-capital will be its policy stance. We see this as evidence 
in support of the mechanism proposed in our theory. We also show that states which are more similar in their labour regulations, tend to have more similar industrial structure.

Our empirics differ from previous work such as Besley and Burgess (2000, 2002) and Aghion, Burgess, Redding and Zilibotti (2003), who focus on the impact of policy on economic performance. Here, in our main econometric specification, we use a measure of policy as our dependent variable, and investigate the impact of capital endowments on policy.

We consider two extensions to the basic model. First, we extend the theory to consider the impact of introducing more goods. Having more goods than factors leads to the possibility of multiple cones of diversification, and hence a return for the role of comparative advantage in determining long-run patterns of specialisation. Now, a country that is relatively capital-abundant will have a lower rental rate than the other country, and this may act as another incentive for capital movements. We also show that introducing costs of capital mobility across countries dampens but does not eliminate the basic result of the model.

The rest of the paper is structured as follows. The next section lays out the theoretical model, stating the two main propositions. Section 3 performs the empirical tests, while section 4 considers extensions to three goods and costs of capital mobility. The final section concludes.

\section{The Model}

The model is a simplified and modified version of Grossman and Helpman (1996), embedded in a factor-endowments model. First, we describe the production side of the economy, which is a standard $2 \times 2 \times 2$ Heckscher-Ohlin model. Assume two countries, Home and Foreign, two goods, 1 and 2, and two factors of production, capital and labour, both inelastically supplied. Let Home be the capital-abundant country, so that $\left(\frac{K}{L}\right)^{H}>\left(\frac{K}{L}\right)^{F}$. The two goods are produced under perfect competition using the following technologies which are assumed to be identical across countries:

$$
\begin{aligned}
X_{1} & =x_{1}(K, L) \quad X_{2}=x_{2}(K, L) \\
\frac{\partial X_{i}}{\partial K} & >0 \quad \frac{\partial X_{i}}{\partial L}>0 \quad \frac{\partial^{2} X_{i}}{\partial K^{2}}<0 \quad \frac{\partial^{2} X_{i}}{\partial L^{2}}<0 \quad i=1,2
\end{aligned}
$$

Assume that good 1 is capital-intensive relative to good 2 at any given factor price: $\left(\frac{K}{L}\right)_{1}>\left(\frac{K}{L}\right)_{2}$. These production functions imply that the Factor Price Equalisation (FPE) set is a subset of the Edgeworth Box. Equilibrium in 
production is given by the set of equilibrium conditions familiar from standard trade theory (see Helpman and Krugman (1985)):

$$
\begin{gathered}
p_{i}=M C_{i}(w, r) \\
l_{1}(w, r) X_{1}+l_{2}(w, r) X_{2}=\bar{L} \\
k_{1}(w, r) X_{1}+k_{2}(w, r) X_{2}=\bar{K} \\
\gamma_{1}\left(p_{1}, p_{2}\right)=\frac{p_{1} X_{1}}{p_{1} X_{1}+p_{2} X_{2}} \\
\gamma_{2}\left(p_{1}, p_{2}\right)=\frac{p_{2} X_{2}}{p_{1} X_{1}+p_{2} X_{2}}
\end{gathered}
$$

where the first condition is simply the zero profit condition, the second condition is the factor market clearing condition, where $l_{i}$ and $k_{i}$ are the unit factor input requirements, and the third condition is the goods market clearing condition, where $\gamma_{1}(p)$ and $\gamma_{2}(p)$ are the shares of goods 1 and 2 respectively in total expenditure.

Next we describe the political side of the economy, which follows Grossman and Helpman $(1996)^{1}$. First we discuss our policy instrument. Since our data uses Besley and Burgess' (2002) indicator of labour regulation as pro-worker or pro-capital, we model the policy instrument in the same way. Policy generates a benefit to capital or labour, and a policy that favours capital automatically hurts labour. Hence, let the net return to capital be $R=r+t$, and the net return to labour be $W=w-t$, where $t$ represents the benefit to capital and can take on any real value. Benefits to factors accrue to factors only, and hence do not enter into the firms' profit maximisation problem. This makes the government's policy choice identical under both autarky and free trade in goods, since the policies do not affect production. Government policy is subject to convex costs in policy which are paid for by the government; this can be justified by saying that small policy measures are more likely to be easy to implement, while large ones tend to be much more difficult to implement:

$$
c(t)=\frac{1}{2} \phi t^{2}
$$

Consumers are divided into those who own labour, whose labour income is $w L$, and those who own capital, whose capital income is $r K$. Suppose that capital owners do not vote, while labour owners vote, and that all capital owners form a single special interest group which can lobby the government, while labour is unorganised (this can be justified based on the free-rider argument).

\footnotetext{
${ }^{1}$ Our exposition actually follows the cleaner version found in Grossman and Helpman (2001) Chapter 10.
} 
Next, we discuss the behaviour of voters and political parties. There are two classes of voters: informed and uninformed. Let $\alpha$ denote the fraction of uninformed voters in the total voting population. An informed voter $i$ votes for party A only if $\left(w-t^{A}\right)-\left(w-t^{B}\right) \geq \beta^{i}$, or if the net return to labour under party A's policy is greater, where $\beta^{i}$ measures the voter's assessment of the superiority or inferiority of party B's exogenous characteristics relative to party A. $t^{A}, t^{B}$ are policy platforms. $\beta^{i}$ is drawn from a uniform distribution on $\left(-\frac{1}{2 f}-\frac{b}{f}, \frac{1}{2 f}-\frac{b}{f}\right)$, where $f>0$ is a parameter measuring the diversity of ex ante views about the parties. The parameter $b$ can be interpreted as the ex ante voter bias in favour of party A. We might expect $b>0$ if party $\mathrm{A}$ is the incumbent party, and $b<0$ if party $\mathrm{B}$ is the incumbent party.

Then the share of informed votes cast for party A equals ${ }^{2}$

$$
s^{I}=\frac{1}{2}+b+f\left[\left(w-t^{A}\right)-\left(w-t^{B}\right)\right]
$$

For uninformed voters, denote by $s^{U}$ the fraction that votes for party A, and assume that it depends linearly on the difference in the parties' total campaign budgets:

$$
s^{U}=\frac{1}{2}+b+h\left(C^{A}-C^{B}\right)
$$

where $h>0$ is a parameter reflecting the productivity of campaign spending, and $C^{P}$ is total campaign spending by party $P, P=A, B$. Assume that the voter bias is the same for both groups of voters.

Seats in parliament are allocated by proportional representation. Then the fraction of the legialature controlled by party A (denoted $s$; this implies that party B controls a share $1-s$ ) matches the fraction of the total votes garnered by this party:

$$
\begin{aligned}
s & =s^{I}+s^{U} \\
& =b+\frac{1}{2}+(1-\alpha) f\left[\left(w-t^{A}\right)-\left(w-t^{B}\right)\right]+\alpha h\left(C^{A}-C^{B}\right)
\end{aligned}
$$

With this specification, if the two parties happen to endorse the same policies, and spend the same amounts on their campaigns, then party A will capture a fraction $\frac{1}{2}+b$ of the votes. For party $\mathrm{A}$, its vote share $s$ is maximised when the party adopts the platform that maximises

$$
G^{A}=(1-\alpha) f\left[w-t^{A}\right]+\alpha h\left(C^{A}\right)
$$

while for party $\mathrm{B}$, its vote share $1-s$ is maximised when the party maximises

$$
G^{B}=(1-\alpha) f\left[w-t^{B}\right]+\alpha h\left(C^{B}\right)
$$

\footnotetext{
on.

${ }^{2}$ We do not simplify the following expression as this form gives a neater interpretation later
} 
Each party maximises a weighted sum of campaign contributions and the welfare of the informed voters. The weight on welfare is greater, the greater is the fraction of informed voters (the larger is $1-\alpha$ ), and the narrower is the range of their ideological view (the larger is $f$ ).

Parties A and B choose their platforms to maximise $s$ and $1-s$ respectively. Each party attempts to implement its announced platform, and a party's probability of success increases monotonically with the size of its legislative delegation. The legislature adopts the policy $t^{A}$ with probability $\varphi(s)$ and $t^{B}$ with probability $1-\varphi(s)$, where $\varphi\left(\frac{1}{2}\right)=\frac{1}{2}$, and $\varphi^{\prime}(s)>0$.

We now consider the behaviour of the special interest group. Denote by $(r+t) K-\frac{1}{2} \phi(t)^{2}$ the aggregate utility that members of the interest group derive from the policy $t$; by including the cost of policy in the objective function of the SIG, we abstract from any externalities in the formation of policy. The objective function of this group is:

$$
\begin{aligned}
V_{L}= & \varphi(s)\left[\left(r+t^{A}\right) K-\frac{1}{2} \phi\left(t^{A}\right)^{2}\right] \\
& +[1-\varphi(s)]\left[\left(r+t^{B}\right) K-\frac{1}{2} \phi\left(t^{B}\right)^{2}\right]-C^{A}-C^{B}
\end{aligned}
$$

We seek a subgame-perfect Nash equilibrium of a two-stage political game. The timing of the game is as follows:

(1) In Stage 1, interest groups announce their contribution schedules to each party.

(2) Then in Stage 2, parties choose their policy platforms. Contributions are paid and campaigns are waged. The election takes place and the legislature meets to implement one of the party's platform. Finally, output is produced.

The key feature of the political model is that it is effectively the lobby that decides government policy through its campaign contributions. The lobby chooses contributions and hence policy to maximise its welfare $V_{L}$, taking as given the two parties' responses to its contributions, while the two parties each choose policy platforms to maximise its vote share, given the platform of the other party and the contribution schedule of the lobby. The lobby is able to exploit the competition for votes between the two parties to set its own agenda. The solution is a Nash equilibrium in contributions and policies.

If the lobby offers nothing to a party, then the party would support the policy that best served the average informed voter, subject to the cost of policy. This policy $t^{*}$ satisfies $\frac{\partial}{\partial t^{*}}\left(\left(w-t^{*}\right)-\frac{1}{2} \phi\left(t^{*}\right)^{2}\right)=0$. So the lobby must guarantee the party at least as many seats as it would capture by endorsing $t^{*}$. Hence it must offer to party A a contribution of at least

$$
C^{A} \geq\left[\frac{(1-\alpha) f}{\alpha h}\right]\left[\left(w-t^{*}\right)-\left(w-t^{A}\right)\right]
$$


Notice that this does not depend on the policy position adopted by party B. Similarly, to induce it to adopt the platform $t^{B}$, the lobby must offer party $\mathrm{B}$ a contribution of at least

$$
C^{B} \geq\left[\frac{(1-\alpha) f}{\alpha h}\right]\left[\left(w-t^{*}\right)-\left(w-t^{B}\right)\right]
$$

The lobby's problem is then to choose $t^{A}, t^{B}$ to maximise its objective function (7), subject to the constraints (8) and (9).

Suppose that the lobby gives the two parties exactly what is needed to induce them to support the platforms $t^{A}$ and $t^{B}$ but nothing more. This is what Grossman and Helpman (1996) refer to as influence-seeking behaviour by the lobby; the lobby contributes in order to influence policy platforms but not the outcome of the election. Then, party A captures a fraction $\frac{1}{2}+b$ of the seats, while party $\mathrm{B}$ captures the remaining fraction $\frac{1}{2}-b$, independently of the policy vectors $t^{A}$ and $t^{B}$. The lobby's problem then becomes one of choosing the two platforms to maximise its expected utility, given contributions that satisfy (8) and (9) with equality. The lobby's objective function then becomes

$$
\begin{aligned}
V_{L}= & \varphi(s)\left[\left(r+t^{A}\right) K-\frac{1}{2} \phi\left(t^{A}\right)^{2}\right]+[1-\varphi(s)]\left[\left(r+t^{B}\right) K-\frac{1}{2} \phi\left(t^{B}\right)^{2}\right] \\
& -\left[\frac{(1-\alpha) f}{\alpha h}\right]\left[2\left(w-t^{*}\right)-\left(w-t^{A}\right)-\left(w-t^{B}\right)\right]
\end{aligned}
$$

Therefore the equilibrium policy platforms satisfy

$$
\begin{aligned}
t^{A} & =\arg \max _{t}\left\{\varphi(s)\left[(r+t) K-\frac{1}{2} \phi t^{2}\right]+\frac{(1-\alpha) f}{\alpha h}(w-t)\right\} \\
t^{B} & =\arg \max _{t}\left\{[1-\varphi(s)]\left[(r+t) K-\frac{1}{2} \phi t^{2}\right]+\frac{(1-\alpha) f}{\alpha h}(w-t)\right\}
\end{aligned}
$$

The influence-seeking lobby induces both parties to behave as if they were maximising weighted sums of the collective welfare of interest group members, and the average welfare of informed workers. Define $\varphi^{A}=\varphi\left(b+\frac{1}{2}\right)$ and $\varphi^{B}=$ $\left[1-\varphi\left(b+\frac{1}{2}\right)\right]$. Then the first order condition implies:

$$
t^{P}=\frac{1}{\phi}\left[K-\left(\frac{(1-\alpha) f}{\varphi^{P} \alpha h}\right)\right] \quad P=A, B
$$

We can easily show that capital is more favourable to capital, the more capital there is in the economy:

$$
\frac{\partial t^{P}}{\partial K}=\frac{1}{\phi}>0
$$

Also, policy is on average more favourable to capital $\left(t^{P}>0\right)$, the larger the share of uninformed voters $(\alpha)$, the less diverse are informed voters' views of the 
two parties $(f)$, the higher the productivity of campaign spending $(h)$, and the more likely is party $\mathrm{P}$ to be able to adopt its announced policy $\left(\varphi^{P}\right)$ (which in turn depends on the exogenous voter preferences for party A versus party B):

$$
t^{P}>0 \quad \text { if } \quad K>\frac{(1-\alpha) f}{\varphi^{P} \alpha h}
$$

Thus we get the following proposition:

Proposition 1 All else equal, the country that has more capital will implement more pro-capital policies $\left(t^{H}>t^{F}\right.$ if $\left.K^{H}>K^{F}\right)$

\subsection{Capital mobility}

Now suppose that we have perfect capital mobility (while labour remains immobile across countries), and suppose that we start from an allocation within the FPE set. The timing of the game is now as follows:

(1) In Stage 1, interest groups announce their contribution schedules to each party.

(2) Then in Stage 2, parties choose their policy platforms. Contributions are paid and campaigns are waged. The election takes place and the legislature meets to implement one of the party's platform. Output is produced.

(3) Finally, capital moves to the country that offers the higher net return.

At first glance it appears that governments would change their policy stance in order to induce capital to flow into the country. This however is not true here, since as noted above, policy is determined by the mobile capital lobbies in each country through their contribution schedules. In this case, lobbies in each country will choose contributions to maximise their welfare, then move to whichever country offers the higher net return. Therefore, introducing capital mobility has no effect on the policy stance of each country.

In equilibrium, because the governments are powerless to determine policy, they also have no control over the distribution of capital across countries. Governments apparently sit still while capital leaves the country en masse, which seems at odds with reality. However, it is not the case that governments do not care about how much capital there is in a country. In the model, governments care about how much capital there is insofar as capital is the source of campaign contributions, and they care about informed voters who vote based on the policy choice of the government. It is simply that the equilibrium of the game implies that capitalist lobbies ultimately determine policy. While this is perhaps a fairly strong outcome, it is not at odds with the fairly widespread belief that powerful global capitalists heavily influence policies in many developing countries.

We describe the resulting allocation of capital across countries diagrammatically, following the analysis of Courant and Deardorff $(1992,1993)$ on trade and amenities with lumpy countries. Because we start from within the FPE set, 
(gross) factor prices are equalised, $r^{H}=r^{F}$, then differences in the net return to capital across countries reflect only differences in policies:

$$
\begin{aligned}
R^{H}= & r^{H}+t^{H}>r^{F}+t^{F}=R^{F} \quad \text { if } K^{H}>K^{F} \\
& R^{H}-R^{F}=t^{H}-t^{F}
\end{aligned}
$$

Perfect capital mobility ensures that capital will move to the country that has more capital. This can be seen in Figure 1, which shows the world Edgeworth box diagram. The FPE set is given by the parallelogram $H A F B$. As long as the allocation of factors lies within the FPE set, the net return to capital will not be equalised across countries. Capital will continue to move across countries, until the net return to capital is equalised. But since $t^{H} \neq t^{F}$, this implies that the gross return to capital is not equalised across countries: $r^{H} \neq r^{F}$. Given that $w^{H}=w^{F}$, this means that the new allocation of resources must lie outside the FPE set.

Where the world allocation of factors ends up depends on the initial allocation. Suppose that we start with an allocation within the FPE set $H A F B$. The possible initial allocations lie within one of four regions, labelled $I, I I, I I I$ and $I V$, where $I I I$ and $I V$ are mirror images of $I$ and $I I$, respectively. Consider an initial allocation lying in region $I$ or $I I$. In this case, $K^{H}>K^{F}$, so $t^{H}>t^{F}$ and capital flows from Foreign to Home. For every initial allocation in regions $I$ and $I I$, we can plot a final allocation such that $R^{H}=R^{F}$. The locus $C F$ traces outer bound of the final allocation; that is, it is the final allocation if the initial allocation lies on the edge of the FPE set, $C A F .{ }^{3}$ For all other allocations in regions $I$ and $I I$, the final allocation lies within the area bounded by the locus $C F$ and $C A F$. Unlike Courant and Deardorff (1993), the locus $C F$ is always a curve, because the difference in policies depends on the initial difference in the level of capital stock.

This can be explained as follows. Starting at point C, where capital stocks (and hence policies) are the same across countries, consider a point along CA just above point C. Then, Home's policy will be slightly more favourable to capital than Foreign's policy, and capital will flow from Foreign to Home. But once a small amount of capital enters Home, the allocation moves outside the FPE set, Home's rental rate falls and, given that there was only a small difference in policy across countries, capital movement stops. As we move up the edge of the FPE set from $C$ to $A$, Home's capital stock relative to Foreign's increases, thus increasing the policy difference between the two countries, and necessitating a larger movement of capital before net returns are equalised across countries. As we continue moving along the edge of the FPE set from $A$ to $F$, Home's policy becomes increasingly favourable to capital, both absolutely and relative to Foreign's. However, as long as both capital and labour are needed to produce

\footnotetext{
${ }^{3}$ This is true for the one-shot game which we describe here. In a multi-period game, as capital endowments diverge across countries, policies also diverge, resulting in further incentives for capital to move.
} 
both goods, it cannot be that all the capital moves to Home ${ }^{4}$. Hence, the boundary of the final allocation is a curve until point $F$. On the other hand, if the initial allocation is in regions $I I I$ or $I V$, then the equilibrium locus is $H D$, which is symmetric to $C F$. In the final equilibrium at least one country is completely specialised in the good which is intensive in its abundant factor.

What is interesting about Figure 1 is that the absolute amount of capital matters for determining the final outcome. For example, in region II, Home is initially labour-abundant relative to Foreign, but because Home has more capital than Foreign, the final allocation has Home as the capital-abundant country. Thus, when policies have this public good feature, patterns of comparative advantage can be reversed by capital mobility. Initial comparative advantage is determined by initial relative factor allocations, while final comparative advantage is determined by initial absolute factor endowments. Of course, this result can be overturned if countries have different parameter values in their political preferences.

Finally, the model has implications for the pattern of specialisation across countries. For the special case when there are two goods, at least one of the countries will always be completely specialised, in the good which is intensive in the factor with which it is well-endowed. Therefore, we get the following testable proposition:

Proposition 2 A country will specialise in the good(s) which are intensive in the factor with which it is relatively well-endowed. Pro-capital policies encourage capital inflows and hence the production of capital-intensive goods.

\section{Empirical evidence}

The finding of the basic model as summarised in Proposition 1 is that, all else equal, states with more capital tend to implement more pro-capital policies, and if there is capital mobility across states, then starting from an allocation within the Factor Price Equalisation (FPE) set, this leads to an inflow of capital to the state with more capital. But while the model was couched in terms of different countries, the same mechanism would also work within countries. In fact, within-country data are more likely to show this effect, since other sources of cross-country heterogeneity in government policies are presumably smaller across states within a country than across countries. Therefore, in this section we consider evidence from India on the relationship between factor endowments and policies.

\footnotetext{
${ }^{4}$ With Cobb-Douglas production functions, the marginal product of a factor becomes infinite as the quantity of the factor approaches zero.
} 


\subsection{Campaign contributions in India}

Our theoretical model is based on the role of campaign contributions in influencing the policy stance of governments. One of our tasks must therefore be to show that campaign contributions do in fact play a significant role in elections in India. Here, we present a brief history of the laws and reality of campaign contributions in India in the last 50 years ${ }^{5}$.

Political parties in India do not receive direct state subsidies. They do receive some subsidised television time and other indirect benefits, such as office space in the capital, but Indian parties raise most of their funds from corporate contributions.

From 1951 to 1969, most private donations to political parties were legal, but public-sector firms were not allowed to make political contributions. Contributions were not subject to limits, but campaign spending itself was limited. In 1969, corporate contributions were banned. Then, in 1975, the Indian Supreme Court ruled that political expenditures not authorised by a candidate do not count towards that candidate's spending limits. As a result of these events, political finance moved underground. When corporate contributions became legal again in 1985, most parties and their corporate benefactors had become used to the underground system of unreported cash or in-kind contributions.

Since 1990, campaign contributions have continued to increase, while expenditure limits remain unrealistically low. But since unauthorised expenditures do not count toward candidate limits, such expenditures technically do not violate the law. In effect, there are no limits either on contributions or expenditures. Not only do researchers not have reliable data on campaign expenditures; the parties themselves may not fully know what was expended in the campaigns. ${ }^{6}$

\subsection{Data and methods}

We perform the analysis for the period 1959-1997, using data on the 16 largest states in India, which account for about $95 \%$ of the total population. The data appendix lists the data sources. Here, we discuss the policy measure and our estimation method. We use the policy measure in Besley and Burgess (2002). They consider amendments to the Industrial Disputes Act of 1947, as listed in Malik (1997) . While all states started out with the same level of policy, statelevel amendments mean that they have diverged over time. Besley and Burgess code 113 amendments to the Act, as either pro-employer, pro-worker, or neutral.

\footnotetext{
${ }^{5}$ The following exposition is based on the report on The Democracy Forum for East Asia's working conference "Political Finance and Democracy in East Asia: The Use and Abuse of Money in Campaigns and Elections", 28-30 June 2001. The report is available online at http://www.ned.org/asia/june01/introduction.html.

${ }^{6}$ Kochanek (1974) is an interesting discussion on the relationship between business and politics in India.
} 
An amendment is coded as +1 if it is pro-worker, -1 if it is pro-employer, and 0 if it is neutral, with multiple amendments in the same direction in the same year given the same coding as if it is a single amendment (for further details, see Besley and Burgess (2002). Figure 2 shows the trends in the policy measure across states. Six states can be classified neutral or control states: Assam, Bihar, Haryana, Jammu \& Kashmir, Punjab and Uttar Pradesh. Another six states are pro-employer: Andhra Pradesh, Karnataka, Kerala, Madhya Pradesh, Rajasthan and Tamil Nadu. Finally, there are four pro-worker states: Gujarat, Maharashtra, Orissa and West Bengal.

Fixed capital stocks across Indian states are shown in Figure 3, which shows the disparity in capital accumulation, with no indication that states with initially less capital are catching up with those that have more capital. We use two alternative estimation methods. First, using OLS, we estimate regressions of the form:

$$
y_{s t}=\alpha_{s}+\beta_{t}+\gamma \ln \left(K_{s t}\right)+\delta x_{s t}+\varepsilon_{s t}
$$

where $y_{s t}$ is the policy measure in state $s$ in year $t . \alpha_{s}$ are the state dummies, which pick up all inter-state differences which are constant over time, and $\beta_{t}$ are year dummies, which control for common shocks. $\ln \left(K_{s t}\right)$ is the $\log$ of capital stock in state $s$ in year $t$, while $x_{s t}$ are other exogenous variables. Equation (13) seeks to uncover the impact of capital endowments on the policy stance of the state government.

Clearly, the capital stock is itself an endogenous variable, therefore we instrument it using the log of total bank credit and the log of the number of bank offices. These capture the impact of financial services on the location of capital; capital needs to locate close to banks to foster close relationships with their bankers. Hence, we then use an instrumental-variables regression with time and state dummies (see Baltagi (2001) or Wooldridge (2002) for expositions). This is simply a two-stage-least-squares generalisation of fixed effects estimation with exogenous variables. We perform the standard Hansen-Sargan test of overidentifying restrictions for the appropriateness of the chosen instruments (Hansen (1982), Sargan (1958); see Hayashi (2000) p. 217-221 or Davidson and MacKinnon (1993) p. 216-217 for exposition)

\subsection{The impact of factor endowments on policy in India}

Table 1 presents the results of our regressions. For each specification we report both OLS and IV results side by side, all with heteroskedastic-robust standard errors. Columns (1) and (2) are the baseline specifications, simply regressing labour regulation on capital endowment (instrumented by the number of bank offices and total bank credit) and state and year dummies. We find that larger capital stocks are associated with lower values of the policy variable; that is, 
larger capital stocks imply more pro-capital policies. The remaining specifications control for other possible factors that might influence policy. Columns (3) and (4) start by considering per capita state development expenditure. This is just significant at the 10 percent level; higher per capita development expenditure is associated with pro-worker policies. In columns (5) and (6), total mandays lost as a result of industrial activity is insignificant. In both cases the effect of fixed capital on policy remains almost unchanged and highly significant. In columns (7) and (8) we separate total mandays lost as a result of industrial activity, to mandays lost as a result of strikes and as a result of lockouts. Interestingly, using OLS, the mandays lost as a result of lockouts is positively related to the policy measure; more lockouts imply more pro-worker policy. The coefficient on capital is still highly significant.

Columns (9) and (10) control for the political history of the states. The identity of the ruling party in a state clearly has great influence on the policy stance. We do indeed find that states which have had more years under a hard left (Communist) party or under the Congress party, have significantly more pro-worker policies than states under the rule of other parties, and (using OLS) states under a Hindu party tend to have pro-capital policies. However, this has almost no effect on the size or the significance of the coefficient on capital. Finally, columns (11) and (12) include all the controls in columns (3) to (10). Once again the coefficient on capital remains highly significant, as are the coefficients on years of rule under a hard left party or the Congress party under both IV and OLS, and for a Hindu party and mandays lost to lockouts under OLS. The number of mandays lost due to lockouts becomes insignificant, suggesting that its effect on the policy variable operates through the identity of the ruling party.

There is some concern in the literature about the special case of West Bengal, as it is the state which has passed the largest number of pro-worker amendments, and has had a declining manufacturing base (see Besley and Burgess (2002)). We find no evidence that West Bengal has had slower accumulation of fixed capital in our sample period (see Figure 3). Nevertheless, our results are robust to excluding any individual state, hence are not driven by outliers.

Finally, because of endogeneity of the capital stock, we prefer the instrumental variables approach to estimation. However, instrumental variables need to be used carefully. Are the instruments we have chosen the appropriate ones?

An appropriate instrument is one which is both uncorrelated with the error term (for consistency), and highly correlated with the instrumented variable (for efficiency). This poses a tradeoff for the researcher, since an instrument which is highly correlated with the instrumented variable, is probably also correlated with the error term. If we have more instruments than instrumented variables, we can use a Sargan (1958) or Hansen $(1978)^{7}$ test of overidentifying restrictions.

\footnotetext{
${ }^{7}$ The Hansen (1978) test is used in the case of heteroskedastic-robust standard errors.
} 
Here, the null hypothesis is that the instruments are valid. The results are in Table 1. We find that the Hansen test is never statistically significant at any conventional level, hence we can conclude that the instruments are valid.

\subsection{First stage and reduced form results}

Table 2 presents the first stage results for the IV estimation, and the reduced form for the main specification (13). These are OLS regressions of the log of fixed capital and of labour regulation, respectively, on the full set of instruments. ${ }^{8}$ The first stage results are reported with normal standard errors (since the first stage does not correct for heteroskedasticity), while the reduced form results are reported with heteroskedastic-robust standard errors.

We find that, controlling for all other variables in the main regression, both total bank credit and number of bank offices have highly significant effects on fixed capital and labour regulation. Controlling for the number of bank offices, total bank credit is positively related to fixed capital, while controlling for total bank credit, the number of bank offices is negatively related to fixed capital. Burgess and Pande (2003) argue that between 1977 and 1990, bank regulations were such that banks were required to open more branches in states with lower initial financial development. On the other hand, total bank credit and number of bank offices have the opposite effects on labour regulation, which suggests that (since fixed capital has a negative effect on labour regulation) that these instruments affect labour regulation mainly through their effect on the capital stock.

Table 1 also reports the F-test of the joint significance of the excluded instruments in the first stage regression. We find that the instruments are always highly jointly significant, and thus play an important role in determining the stock of fixed capital.

\subsection{Industrial specialisation in India, 1980-1997}

To test the second main prediction of the model as stated in Proposition 2, we make use of more detailed data at the 3-digit-industry-state level, for which data is available between 1980 and 1997. To restate Proposition 2 in a different way, the greater is the difference in policies across states, the greater will be the difference in their industrial structure. We can therefore test this proposition using a simple formulation adapted from Bernard, Redding, Schott and Simpson (2003). We run the following regression:

$$
I_{r s}=\lambda_{0}+\lambda_{1}\left|\eta_{r s}\right|+\lambda_{2} I_{r}+\lambda_{3} I_{s}+v_{r s}
$$

\footnotetext{
${ }^{8}$ These are applicable for the full specification in column (11) of Table 1 . We get very similar results with the fewer controls in other columns of Table 1.
} 
where $I_{r}$ and $I_{s}$ are the number of industries in states $r$ and $s, I_{r s}$ is the number of industries common to both state $r$ and $s$, and $\left|\eta_{r s}\right|$ are the absolute differences in the measure of labour regulation between states $r$ and $s$. The idea is that the larger is the value of $\left|\eta_{r s}\right|$, the more different are policies and hence factor endowments across states, and therefore the fewer industries the two states should have in common. Therefore we expect $\lambda_{1}$ to be negative.

Table 3 presents the results with heteroskedastic-robust standard errors. Column (1) is the basic specification following equation (14). All variables are very highly significant and consistent with our priors. The total number of industries in each state have very strong positive effects on the number of common industries in the two states, and the absolute difference in labour regulation has a strong negative impact. The remaining columns add state and year dummies to control for unobserved variation across states and across time, respectively. In column (2), controlling for years has almost no effect on the parameters of interest. Including dummies for states $r$ and $s$ (column (3)) reduces the absolute value and t-statistic of tge coefficients of interest, but they remain highly significant. Finally, column (4) including both state and time dummies does not alter the results dramatically.

\section{Theoretical Extensions}

The simple setup of the basic model makes it amenable to many possible extensions. In this section we consider two large extensions. First, we extend the analysis to the case of three goods, which allows for the possibility of multiple cones of diversification and the return of comparative advantage in playing a role in determining the final allocation of factors. Next, we consider the impact of introducing a cost of capital mobility, which allows the possibility that the final outcome need not lie outside the FPE set.

\subsection{Multiple cones of diversification}

In this subsection, we introduce a third good into the model. Introducing more than two goods allows for the possibility of multiple cones of diversification, and hence the possibility that, unlike in the two-good case, relative factor abundance plays a role in determining the direction of capital flows. Suppose that there are three goods. It is possible that parameter values are such that factor prices are not equalised across countries (see e.g. Deardorff (1993)). In this case, we may have both countries being incompletely specialised, but as Deardorff (1993) shows, the tendency will still be for a country to produce the good in which it has a comparative advantage.

Consider for example Figure 4, which shows the Lerner-Pearce diagram for three goods (1, 2 and 3 ) and two factors (K and L). Goods prices $p_{1}, p_{2}$, and 
$p_{3}$ are determined through goods market clearing conditions, and enter the diagram by determining the position of the unit-value isoquants, $X_{1}=\frac{1}{p_{1}}$, $X_{2}=\frac{1}{p_{2}}$, and $X_{3}=\frac{1}{p_{3}}$. As we have drawn it, there is no common tangent to all three isoquants. Instead, there is one unit isocost line tangent to the unit value isoquants for $X_{1}$ and $X_{2}$, with corresponding factor prices $w^{1}$ and $r^{1}$, and a second unit isocost line tangent to the unit value isoquants for $X_{2}$ and $X_{3}$, with factor prices $w^{2}$ and $r^{2}$. At the first set of factor prices, goods 1 and 2 can both be produced, using capital-labour ratios $k_{1}$ and $k_{2}^{1}$, but good 3 cannot. At the second set of factor prices, goods 2 and 3 can be produced using capital-labour ratios $k_{2}^{2}$ and $k_{3}$, but good 1 cannot be produced.

In Figure 4, there are many possible patterns of specialisation and factor prices. ${ }^{9}$ Which outcome occurs for a country depends on its factor endowments. If a country's endowment lies within the first diversification cone between $k_{1}$ and $k_{2}^{1}$, then it will produce goods 1 and 2 , and face factor prices $w^{1}$ and $r^{1}$. If it lies within the second diversification cone between $k_{2}^{2}$ and $k_{3}$, then it will produce goods 2 and 3 , and face factor prices $w^{2}$ and $r^{2}$. If it lies outside of the two cones, then it will be completely specialised in one of the three goods.

If there are two countries, factor prices cannot be equalised across countries, as long as all three goods are demanded in equilibrium. In Figure 5, where we focus on the upper-left of the diagram, the possible initial allocation of factors such that all three goods are produced are in regions I, II and III. Outside of these three regions, the three goods cannot be produced with this set of factor prices, and if all three goods are demanded, then factor prices (and hence production techniques) must adjust until all three goods are produced. For example, consider region V. Here, Foreign is producing goods I and II, and Home is producing good II. Since no one is producing good III, the price of good 3 rises, raising the return to capital, reducing the slope of all the capitallabour ratios in Figure 5 until all three goods are being produced.

What does this imply for the impact of policy on the movement of capital across locations? Suppose that the two countries lie in different cones (this must be the case for all three goods to be produced), that Home is capital-abundant relative to Foreign, such that $\left(\frac{K}{L}\right)^{H}>\left(\frac{K}{L}\right)^{F}$, and hence that $r^{H}<r^{F}$, and also suppose that the initial allocation of factors lies within region I (this is the case where both countries are incompletely specialised $)^{10}$. There are three possibilities:

$$
\begin{array}{ll}
\text { Case } 1 & R^{H}=r^{H}+t^{H}>r^{F}+t^{F}=R^{F} \\
\text { Case2 } & R^{H}=r^{H}+t^{H}=r^{F}+t^{F}=R^{F} \\
\text { Case3 } & R^{H}=r^{H}+t^{H}<r^{F}+t^{F}=R^{F}
\end{array}
$$

\footnotetext{
${ }^{9}$ Recent evidence suggests that FPE fails, both within and across countries. See for example, Cunat (1999), Schott (2003), Bernard and Schott (2002), Bernard, Redding, Schott and Simpson (2003).

${ }^{10}$ The case where Foreign is the capital-abundant country is symmetrical to this one.
} 
Case 1 implies that $t^{H} \gg t^{F}$, or $K^{H} \gg K^{F}$; case 2 implies that $t^{H}>t^{F}$, or $K^{H}>K^{F}$; while case 3 implies that $t^{H} \gtrless t^{F}$, or $K^{H} \gtrless K^{F}$. For any given difference between the rental rates in the two countries, there is a given difference in the policy measure (and hence capital stock) for which case 2 holds. This is represented in Figure 5 by the bold horizontal line $x y$. Then, case 1 holds whenever the initial allocation lies above $x y$, and case 3 occurs whenever the allocation lies below $x y$.

In case 2 , because the net return to capital is equalised in the two countries, there is no movement of capital. In case 1, capital moves to the capital-abundant country Home, with the locus $x z$ representing the final allocation of factors if the initial allocation is on the edge of region I; the explanation for its shape is given above in section 2.2. When $x z$ lies in region IV, since good 2 is not being produced, factor prices adjust until the locus lies within one of regions I, II or III. On the other hand, in case 3, capital moves to the labour-abundant country Foreign. The scarcity of capital in Foreign implies a higher return to capital in Foreign, and here this return is so much higher than that in Home that the net return to capital is higher in the labour-abundant country. The locus yw traces out the equilibrium allocations of factors when the initial allocation is on the edge of region I. What in fact happens of course is that the factor prices and hence capital-labour ratios in both countries will adjust so that this locus will always lie within region I.

Therefore, extending ths model to three goods enriches it by re-introducing the role of relative factor abundance as a determinant of the final allocation of factors in the world economy. Somewhat perversely, in a multi-cone case, a country that is relatively capital-abundant finds it more difficult to attract capital, since it has a lower rental rate than the other country ${ }^{11}$. It also introduces new patterns of specialisation across countries. In case 2, both countries remain incompletely specialised, with Home producing goods 2 and 3, and Foreign producing 1 and 2 . In case 1 , if the final outcome lies within region II, then Foreign produces good 1, while Home produced goods 2 and 3, while if in region III, then Foreign produces goods 1 and 2, while Home produces only good 3. Finally, in case 3 , since the final outcome always lies within region 1 , patterns of specialisation are as in case 1 .

\subsection{Costly capital mobility}

The model above assumes perfect capital mobility, which is not completely true in the real world. In this subsection, we discuss the implications of introducing costs of capital mobility.

\footnotetext{
${ }^{11}$ This may be a possible explanation for the relative stagnation of West Bengal as reported by Besley and Burgess (2002). While it was capital-abundant relative to other Indian states in the 1950 s, a combination of pro-worker policies and low returns to capital have made further capital accumulation difficult.
} 
Haufler (1997) shows that allowing for mobility costs acts as a restriction to the amount of capital flows across countries. In particular, capital owners trade off the gains from locating in a country with a higher return to capital, with the cost of moving. Applying this idea to our model, the result hinges on the specification of the mobility cost. Suppose that it is a linear function, $C_{H F}=$ $c_{H F} K_{H F}$, where the subscripts denote values for the movement of capital from Home to Foreign. Then, the marginal cost of movement is $c_{H F}$, so that, if $t^{F}>t^{H}$, then if factor prices are equalised $\left(r^{H}=r^{F}\right)$, capital will move from Home to Foreign only if $t^{F}-c_{H F}>t^{H}$. Similarly, if $t^{F}<t^{H}$, capital will move from Foreign to Home only if $t^{F}<t^{H}-c_{H F}$. This implies that there is a range for the policy measures $t^{H}$ and $t^{F}$ such that capital will not move despite differences in policies across countries:

$$
c_{H F}>\left|t^{H}-t^{F}\right|=\frac{1}{\phi}\left|K^{H}-K^{F}\right|
$$

If the marginal cost of movement is very high, then countries can have very different policies towards capital and still not provoke capital to move across countries. However, if the inequality does not hold, then capital will still move across countries until factor prices are no longer equalised. This can be seen in Figure 6. If the initial allocation of resources lies within the parallelogram $M N Q P$, then $c_{H F}>\left|t^{H}-t^{F}\right|$ so that there is no capital movement across countries. Outside of this parallelogram, the inequality is reversed so that capital flows from one country to another. The locus representing the boundary of the final allocation is given by the curve $P F$ (and $N H$ ). Comparing this with the no-mobility-cost loci $C F$ and $D H, P F$ and $N H$ are always closer to the FPE set, since there is a cost of mobility.

On the other hand, if, as Haufler (1997) assumes, the mobility cost is convex, $C_{H F}=\frac{1}{2} c_{H F} K_{H F}^{2}$, then the marginal cost of mobility is $c_{H F} K_{H F}$, increasing in the volume of capital movement, so that if policies differ across countries, it always pays for small amounts of capital to move between countries. This time, capital will stop moving across countries while still within the FPE set if

$$
c_{H F} K_{H F}>\left|t^{H}-t^{F}\right|=\frac{1}{\phi}\left|K^{H}-K^{F}\right|
$$

Clearly whether or not this holds depends on how far from the edge of the FPE set was the initial endowment point. Figure 7 shows the possibilities. If the initial allocation lies within the area $C G D E$, then the final allocation will lie within the FPE set, as eventually the cost of moving outweighs the gain in return. The line $C G$ is not parallel to $C A F$, since, as we move from $C$ to $G$, the difference between the two countries' policies increases, thus more capital flows will occur before the costs start to outweigh the benefits. As before, if the initial allocation lies outside this area, then the final allocation lies outside the FPE set, and the boundary of the final allocation is given by the locus $C C$ " $F$, 
which always lies closer to the FPE set than for the case with no mobility cost as represented by $C C^{\prime} F .^{12}$

Therefore, introducing mobility costs into the model will dampen but not eliminate the basic result that, starting from an allocation within the FPE set, capital flows to the country which initially has more capital. Whether or not capital moves and whether the final allocation of factors lies within the FPE set, depend on the initial allocation.

\section{Conclusions}

The main contribution of this paper is to develop and test empirically a model of electoral competition and campaign contributions that has implications for the structure of economic activity. The model makes two main theoretical predictions. First, it predicts that countries or states that have large absolute levels of capital stock tend to implement policies which are more favourable to capital. To overcome the endogeneity issues, we use two-stage-least-squares estimation. The model's prediction is found to hold true across states in India in the period 1959-1997, even after controlling for various other factors that could influence the policy stance. A second prediction of the model is that countries with pro-capital policies tend to be relatively capital-abundant and hence tend to specialise in capital-intensive goods. This is also confirmed in the data.

We extend the theoretical model to consider the impact of introducing more goods and costs of capital mobility. Introducing more goods leads to the possibility of the existence of multiple cones of diversification, and hence for a role for comparative advantage in determining the final allocation of resources. One interesting implication of this is that countries that initially have a comparative advantage in capital-intensive goods, tend to find it more difficult to attract more capital as a result of factor price differences. On the other hand, incorporating costs of capital mobility to the model dampens the basic model's result that the final allocation of resources always lies outside the FPE set. Once there are costs of capital mobility, there are initial allocations of resources such that capital has no incentive to move across countries, and hence that the final allocation of resources remains within the FPE set.

Our results have broader implications for the process of policy formation. Most importantly, states which are initially disadvantaged in the sense of having less capital stock, face difficulties in catching up with states that are better endowed initially. The political structure leads capital-poor states to implement policies that are less favourable to capital. Therefore, our findings call for a reconsideration of the role of campaign contributions in elections, and also for

\footnotetext{
${ }^{12}$ Comparing the loci for the two types of mobility costs is more difficult, since they may or may not intersect one another depending on parameter values.
} 
a reevaluation of the costs and benefits of regional integration, especially for smaller countries.

\section{References}

[1] Aghion, Phillipe, Robin Burgess, Stephen Redding and Fabrizio Zilibotti (2003), "The Unequal Effects of Liberalization: Theory and Evidence from India", mimeo, London School of Economics.

[2] Baltagi, Badi H. (2001), Econometric Analysis of Panel Data, Second Edition, Chichester, John Wiley.

[3] Bernard, Andrew B. and Peter K. Schott (2002), "Factor Price Equality and the Economies of the United States", revised version of NBER Working Paper 8068.

[4] Bernard, Andrew B., Stephen Redding, Peter K. Schott and Helen Simpson (2003), "Factor Price Equalization in the UK? A General Test and Evidence", revised version of NBER Working Paper 9052.

[5] Besley, Timothy and Robin Burgess (2000), "Land Reform, Poverty and Growth: Evidence from India", Quarterly Journal of Economics, 105(2): $389-430$.

[6] Besley, Timothy and Robin Burgess (2003), "Can Labour Regulation Hinder Economic Performance? Evidence from India", mimeo, London School of Economics.

[7] Burgess, Robin and Rohini Pande (2003), "Do Rural Banks Matter? Evidence from the Indian Social Banking Experiment", mimeo, London School of Economics.

[8] Butler, David, Ashok Lahiri and Prannoy Roy (1991), India Decides: Elections 1952-1991, New Delhi, Aroom Purie for Living Media India.

[9] Courant, Paul N. and Alan V. Deardorff (1992), "International Trade with Lumpy Countries", Journal of Political Economy, 100(1): 198-210.

[10] Courant, Paul N. and Alan V. Deardorff (1993), "Amenities, Nontraded Goods, and the Trade of Lumpy Countries", Journal of Urban Economics, 34(2), 299-317.

[11] Cunat, Alejandro (2000), "Can International Trade Euqalize Factor Prices?", mimeo, London School of Economics.

[12] Davidson, Russell and James G. MacKinnon (1993), Estimation and Inference in Econometrics, New York, Oxford University Press. 
[13] Deardorff, Alan V. (1993), "Directions of Lumpy Country Trade", in Wilfred J. Ethier, Elhanan Helpman and J. Peter Neary (eds.), Theory, Policy and Dynamics in International Trade, Cambridge, Great Britain, Cambridge University Press.

[14] Gawande, Kishore and Usree Bandyopadhyay (2000), "Is Protection for Sale? A Test of the Grossman-Helpman Theory of Endogenous Protection", Review of Economics and Statistics, 82(1): 139-152.

[15] Goldberg, Pinelopi and Giovanni Maggi (1999), "Protection for Sale: An Empirical Investigation", American Economic Review, 89(5): 833-850.

[16] Grossman, Gene M. and Elhanan Helpman (1994), "Protection for Sale", American Economic Review, 84(4): 833-850.

[17] Grossman, Gene M. and Elhanan Helpman (1996), "Electoral Competition and Special Interest Politics", Review of Economic Studies, 63(2): 265-286.

[18] Grossman, Gene M. and Elhanan Helpman (2001), Special Interest Politics, Cambridge, MA, MIT Press.

[19] Hansen, Lars Peter (1982), "Large Sample Properties of Generalized Method of Moments Estimators", Econometrica, 50(4): 1029-1054.

[20] Haufler, Andreas (1997), "Factor Taxation, Income Distribution and Capital Market Integration", Scandinavian Journal of Economics, 99(3): 425446.

[21] Hausman, Jerry A (1978), "Specification Tests in Econometrics", Econometrica, 46(6): 1251-1271.

[22] Hayashi, Fumio (2000), Econometrics, Princeton, New Jersey, Princeton University Press.

[23] Helpman, Elhanan and Paul R. Krugman (1985), Market Structure and Foreign Trade, Cambridge, MA, MIT Press.

[24] Kochanek, Stanley A. (1974), Business and Politics in India, Los Angeles, CA, University of California Press.

[25] Malik, P. L. (1997), Industrial Law, Lucknow, India, Eastern Book Company.

[26] Persson, Torsten and Guido Tabellini (1992), "The Politics of 1992: Fiscal Policy and European Integration", Review of Economic Studies, 59(4), 689701.

[27] Persson, Torsten and Guido Tabellini (1999), Political Economics: Explaining Economic Policy, Cambridge, MA, MIT Press. 
[28] Political Finance and Democracy in East Asia: The Use and Abuse of Money in Campaigns and Elections: Proceedings of the Working Conference held in Seoul, Korea, 28-30 June 2001 (available at http://www.ned.org/asia/june01/introduction.html).

[29] Sargan, J. D. (1958), "The Estimation of Economic Relationships Using Instrumental Variables", Econometrica, 26(3): 393-415.

[30] Schott, Peter K. (2003), "One Size Fits All? Heckscher-Ohlin Specialization in Global Production", American Economic Review, 93(2): 686-708.

[31] Wooldridge, Jeffrey M. (2002), Econometric Analysis of Cross Section and Panel Data, Cambridge, MA, MIT Press.

\section{Data Appendix}

Our data comes from many sources. Population data is from the Indian censuses in 1951, 1961, 1971, 1981 and 1991 (Census of India, Registrar General and Census Commissioner, Government of India). Installed electrical generating capacity per capita is from the Statistical Abstract of India (Central Statistical Office, Department of Statistics, Ministry of Planning, Government of India). Development expenditure is from the Public Finance Statistics, (Ministry of Finance, Government of India). Fixed capital is from the Annual Survey of Industries (Central Statistical Office (Industrial Statistics Wing), Department of Statistics, Ministry of Planning and Programme Implementation, Government of India). Annual mandays lost to strikes and lockouts is from the Indian Labour Yearbook (Labour Bureau, Ministry of Labour, Government of India).

Data on political histories comes from Butler, Lahiri and Roy (1991), updated from the website of the Election Commission of India (http://www.eci.gov.in/). Political history is measured by the number of years during our data period that political groupings have held a majority in the state legislature. The groupings are: the Congress party, the Janata parties, hard left parties, Hindu parties, and regional parties. 
Figure 1: Initial and final distribution of endowments.

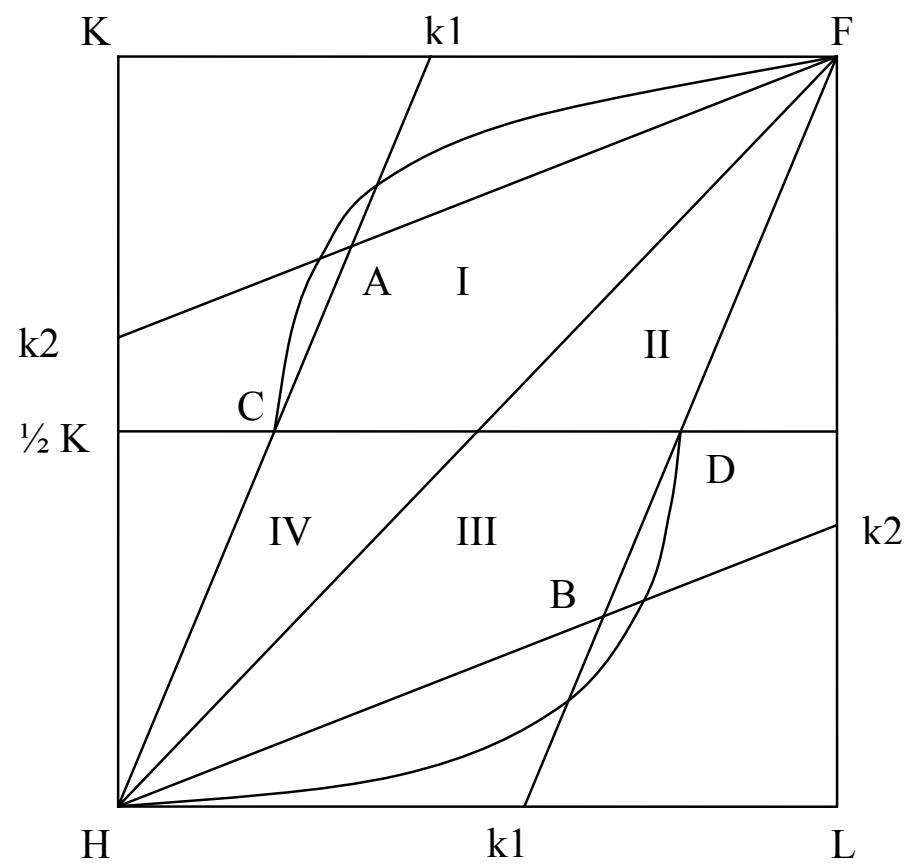

Figure 2: Labour regulation in India, 1958-1997.

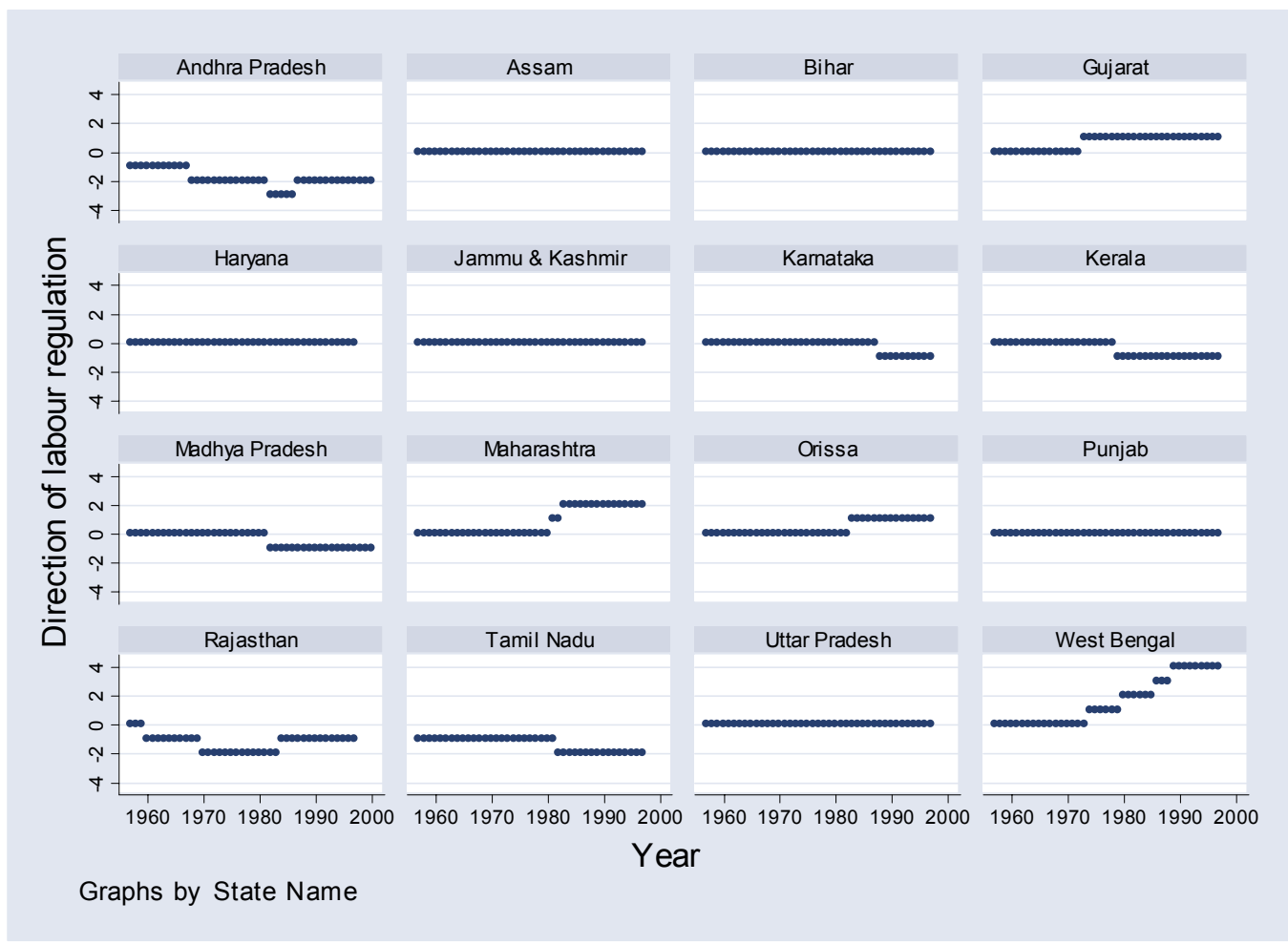


Figure 3: Log of fixed capital.

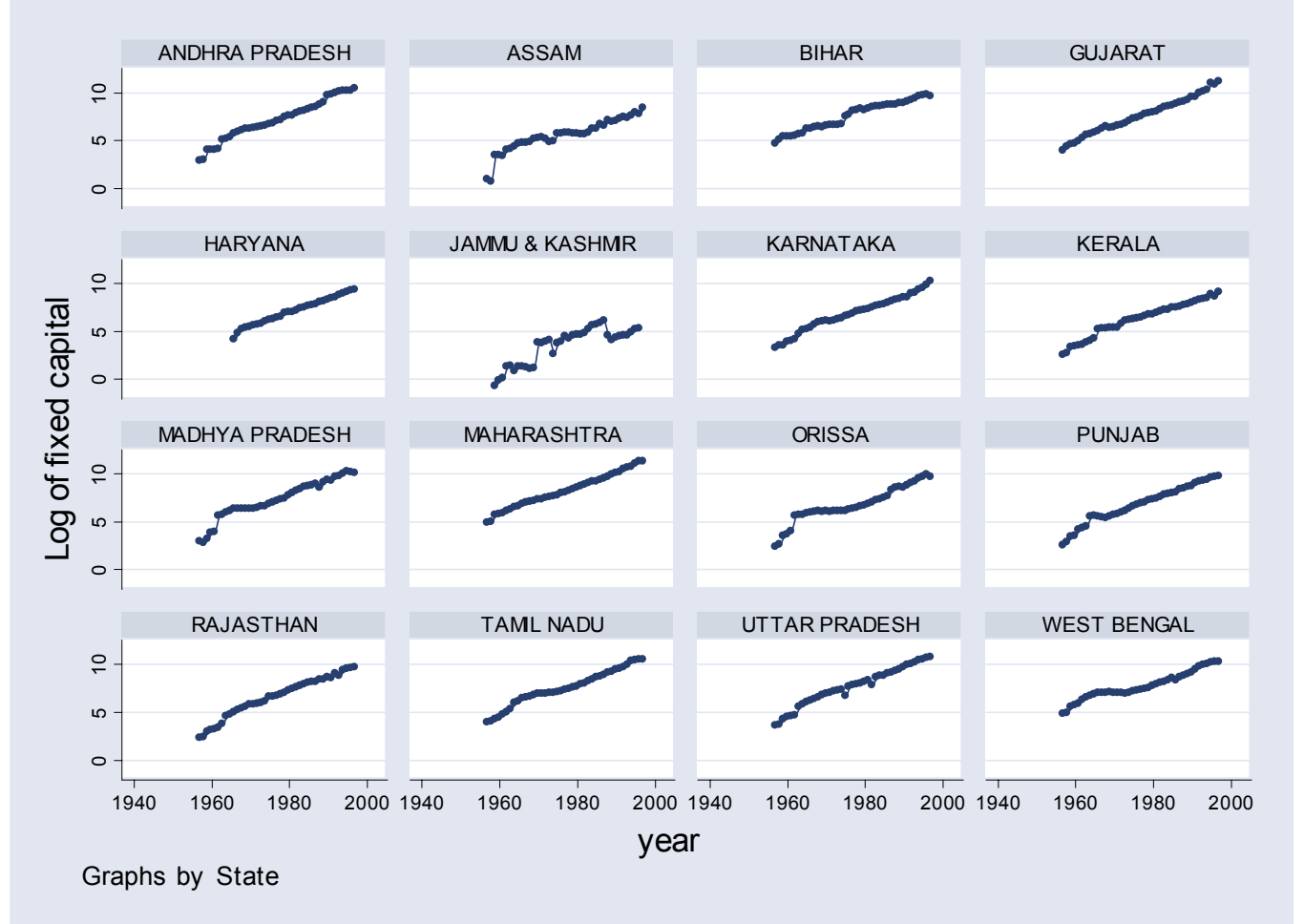

Figure 4: Lerner-Pearce diagram showing two factors and three goods with two cones of diversification.

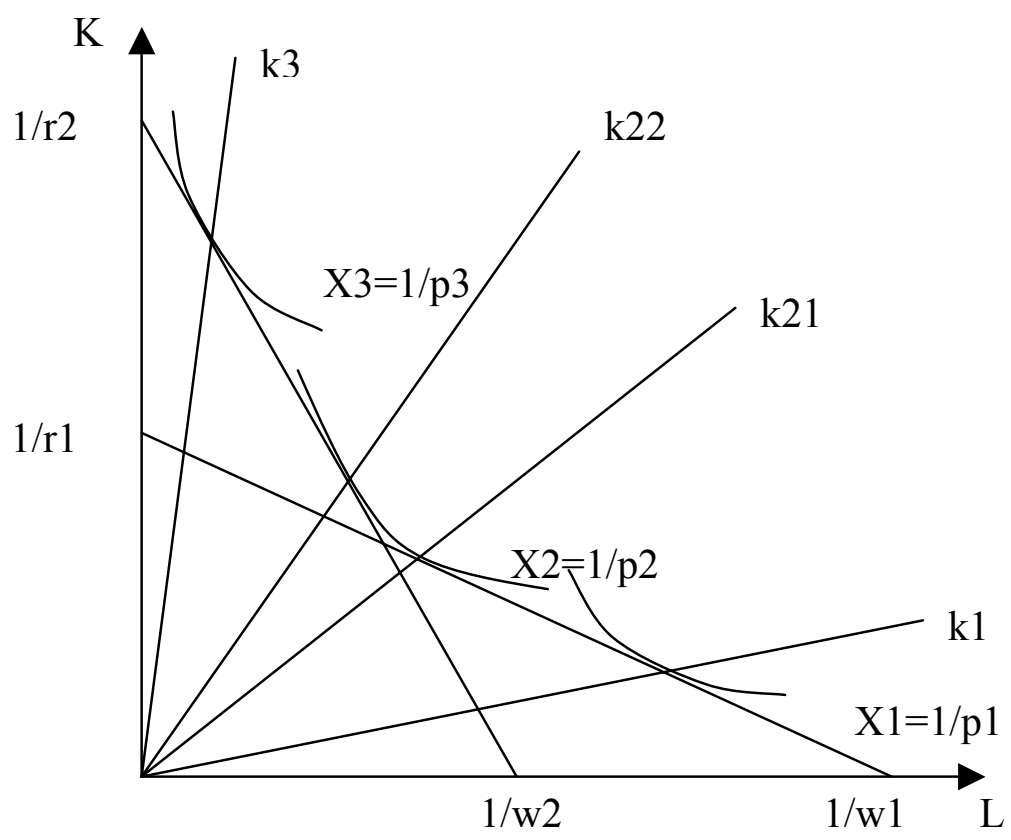


Figure 5: Edgeworth Box diagram with three goods and multiple cones of diversification.

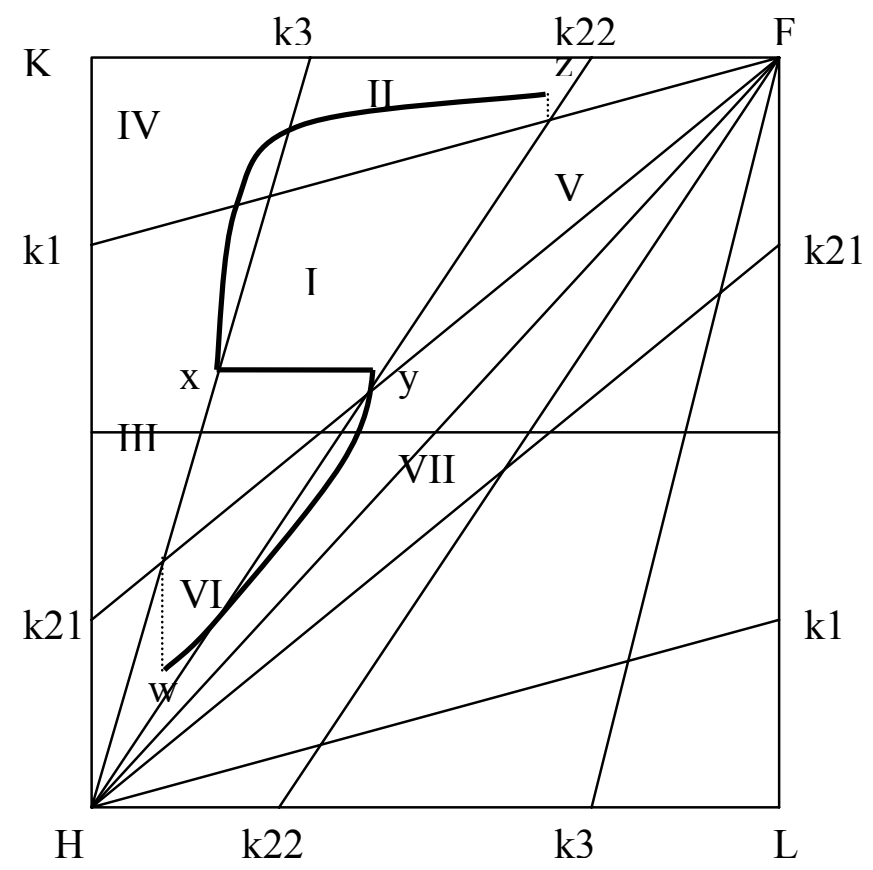

Figure 6: Edgeworth Box diagram with linear mobility costs.

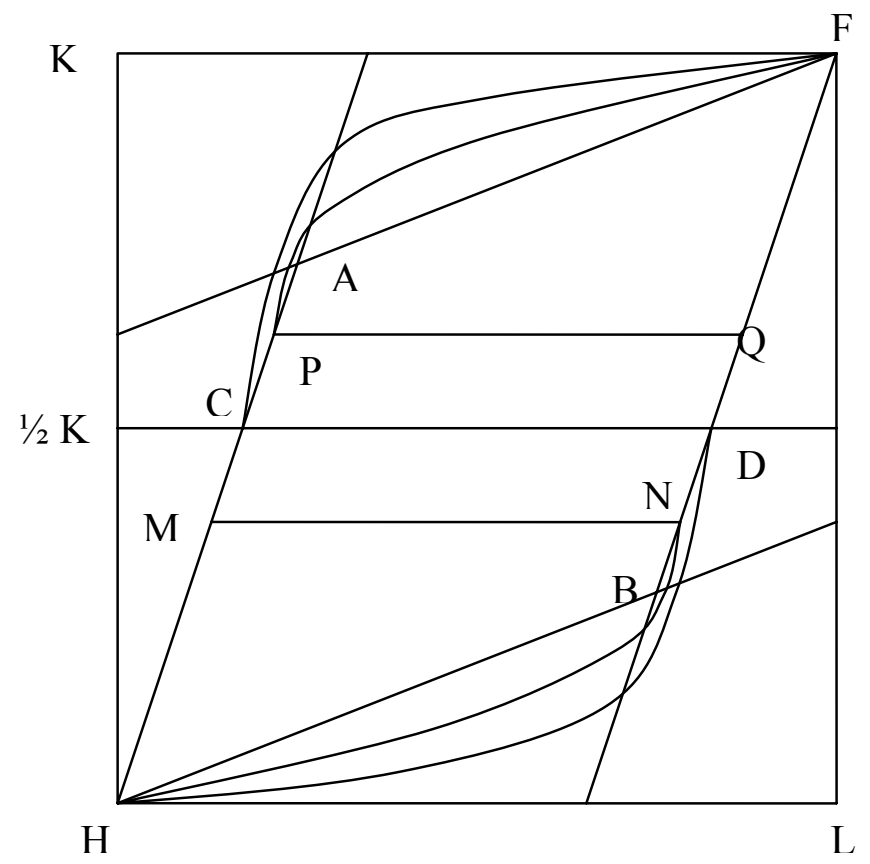


Figure 7: Edgeworth Box diagram with quadratic mobility costs.

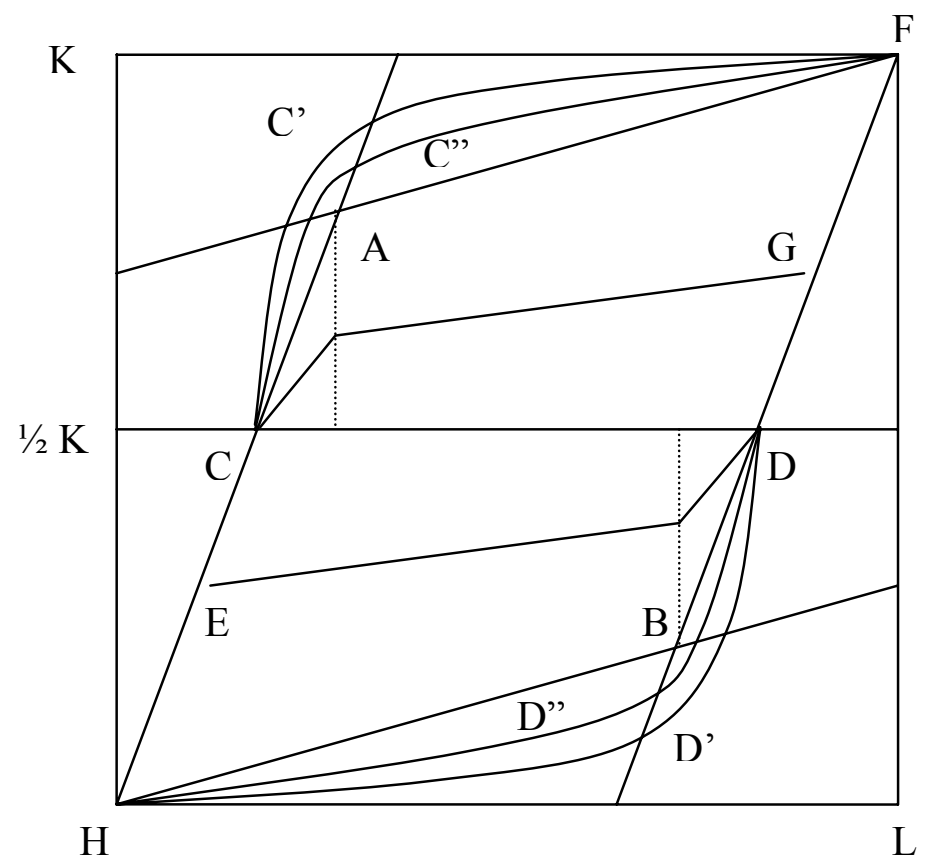


Table 1: IV and OLS results for the measure of labour regulation.

\begin{tabular}{|c|c|c|c|c|c|c|c|c|c|c|c|c|}
\hline & (1) & $(2)$ & (3) & (4) & $(5)$ & $(6)$ & (7) & $(8)$ & (9) & $(10)$ & $(11)$ & (12) \\
\hline Dependent variable & \multicolumn{12}{|c|}{ Labour regulation } \\
\hline & IV & OLS & IV & OLS & IV & OLS & IV & OLS & IV & OLS & IV & OLS \\
\hline \multirow[t]{2}{*}{ Log of fixed capital } & -2.275 & -0.279 & -3.178 & -0.266 & -2.789 & -0.273 & -2.996 & -0.197 & -1.613 & -0.180 & -2.507 & -0.144 \\
\hline & $(5.29)^{* *}$ & $(4.75)^{* *}$ & $(5.33)^{* *}$ & $(4.48)^{* *}$ & $(5.38)^{* *}$ & $(4.64)^{* *}$ & $(4.59)^{* *}$ & $(3.52)^{* *}$ & $(3.28)^{* *}$ & $(3.61)^{* *}$ & $(3.50)^{* *}$ & $(2.58)^{*}$ \\
\hline \multirow[t]{2}{*}{ Janata majority } & & & & & & & & & 0.026 & -0.008 & 0.045 & -0.005 \\
\hline & & & & & & & & & $(0.90)$ & $(0.39)$ & $(1.20)$ & $(0.23)$ \\
\hline \multirow[t]{2}{*}{ Hindu majority } & & & & & & & & & -0.125 & -0.280 & -0.006 & -0.277 \\
\hline & & & & & & & & & $(0.95)$ & $(3.06)^{* *}$ & $(0.03)$ & $(3.07)^{* *}$ \\
\hline \multirow[t]{2}{*}{ Hard left majority } & & & & & & & & & 0.160 & 0.208 & 0.146 & 0.180 \\
\hline & & & & & & & & & $(4.35)^{* *}$ & $(8.03)^{* *}$ & $(3.65)^{* *}$ & $(5.97)^{* *}$ \\
\hline \multirow[t]{2}{*}{ Regional majority } & & & & & & & & & 0.016 & -0.001 & 0.004 & -0.002 \\
\hline & & & & & & & & & $(1.02)$ & $(0.13)$ & $(0.16)$ & $(0.25)$ \\
\hline \multirow[t]{2}{*}{ Congress majority } & & & & & & & & & 0.048 & 0.042 & 0.045 & 0.038 \\
\hline & & & & & & & & & $(4.23)^{* *}$ & $(4.67)^{* *}$ & $(2.86)^{* *}$ & $(4.05)^{* *}$ \\
\hline \multirow{2}{*}{$\begin{array}{l}\text { Mandays lost to lockouts } \\
\text { per capita }\end{array}$} & & & & & & & 0.001 & 0.010 & & & -0.002 & 0.004 \\
\hline & & & & & & & $(0.27)$ & $(4.85)^{* *}$ & & & $(0.56)$ & $(2.60) * *$ \\
\hline \multirow{2}{*}{$\begin{array}{l}\text { Mandays lost to strikes } \\
\text { per capita }\end{array}$} & & & & & & & -0.001 & -0.000 & & & -0.001 & -0.000 \\
\hline & & & & & & & $(0.84)$ & $(0.18)$ & & & $(0.93)$ & $(0.37)$ \\
\hline \multirow{2}{*}{$\begin{array}{l}\text { Development } \\
\text { expenditure per capita }\end{array}$} & & & 95.384 & -16.678 & & & & & & & 50.901 & -10.753 \\
\hline & & & $(1.75)$ & $(1.74)$ & & & & & & & $(0.96)$ & $(1.06)$ \\
\hline \multirow{2}{*}{$\begin{array}{l}\text { Mandays lost to } \\
\text { industrial disputes } \mathrm{p} / \mathrm{c}\end{array}$} & & & & & -0.001 & 0.001 & & & & & & \\
\hline & & & & & $(0.76)$ & $(1.62)$ & & & & & & \\
\hline State dummies & Yes & Yes & Yes & Yes & Yes & Yes & Yes & Yes & Yes & Yes & Yes & Yes \\
\hline Year dummies & Yes & Yes & Yes & Yes & Yes & Yes & Yes & Yes & Yes & Yes & Yes & Yes \\
\hline Observations & 613 & 613 & 607 & 607 & 607 & 607 & 574 & 574 & 613 & 613 & 574 & 574 \\
\hline Hansen test & 1.81 & & 0.02 & & 0.00 & & 0.21 & & 1.60 & & 1.91 & \\
\hline $\operatorname{Prob}(\mathrm{H})>$ chi2 & 0.18 & & 0.90 & & 0.97 & & 0.65 & & 0.21 & & 0.17 & \\
\hline R-squared & & 0.68 & & 0.69 & & 0.69 & & 0.72 & & 0.75 & & 0.76 \\
\hline Excluded variables F-test & 31.73 & & 18.27 & & 22.71 & & 15.97 & & 25.28 & & 12.08 & \\
\hline Prob $>F$ & 0.0000 & & 0.0000 & & 0.0000 & & 0.0000 & & 0.0000 & & 0.0000 & \\
\hline
\end{tabular}

Notes: Robust z statistics in parentheses. * significant at $5 \%$; ** significant at $1 \%$. In the IV regression, fixed capital is assumed to be endogenous, and is instrumented using installed electricity generating capacity. Heteroskedasticity-robust standard errors reported. All regressions run with state and year fixed effects. The number of observations varies across specifications because not all variables are available for all observations. 
Table 2: First stage and reduced-form regressions.

\begin{tabular}{|l|c|c|}
\hline & $(1)$ & $(2)$ \\
\hline Dependent variable & Log of fixed capital & Labour regulation \\
\hline Log of total bank credit & 0.335 & -1.084 \\
\hline & $(4.04)^{* *}$ & $(4.52)^{* *}$ \\
\hline Log of number of bank offices & -0.416 & $(5.05)^{* *}$ \\
\hline & $(4.69)^{* *}$ & 38.226 \\
\hline \multirow{2}{*}{$\begin{array}{l}\text { Development expenditure per } \\
\text { capita }\end{array}$} & 14.146 & $(2.99)^{* *}$ \\
\hline Mandays lost to lockouts per \\
capita & $(1.33)$ & 0.002 \\
\hline Mandays lost to strikes per capita & -0.002 & $(1.26)$ \\
\hline & $(1.92)$ & -0.000 \\
\hline Janata majority & -0.000 & $(0.41)$ \\
\hline & $(0.90)$ & -0.007 \\
\hline Hindu majority & 0.028 & $(0.35)$ \\
\hline & $(1.53)$ & -0.291 \\
\hline Hard left majority & 0.128 & $(3.00)^{* *}$ \\
\hline & $(1.41)$ & 0.113 \\
\hline Regional majority & 0.010 & $(3.39)^{* *}$ \\
\hline & $(0.64)$ & -0.009 \\
\hline Congress majority & 0.004 & $(0.96)$ \\
\hline & $(0.49)$ & 0.029 \\
\hline State dummies & 0.006 & $(3.27)^{* *}$ \\
\hline Year dummies & $(0.99)$ & Yes \\
\hline Observations & Yes & 574 \\
\hline R-squared & Yes & 0.80 \\
\hline Notes: Abshus & 574 & $1 \% .001$ \\
\hline
\end{tabular}

Notes: Absolute value of t statistics in parentheses. * significant at 5\%; ** significant at 1\%. Column (1) presents the first stage results with non-robust standard errors, while column (2) presents the reduced-form with heteroskedastic-robust standard errors. 
Table 3: Industry overlap and labour regulation.

\begin{tabular}{|c|c|c|c|c|}
\hline & $(1)$ & $(2)$ & (3) & $(4)$ \\
\hline Dependent variable & \multicolumn{4}{|c|}{ Number of industries common to states $\mathrm{r}$ and $\mathrm{s}$} \\
\hline \multirow{2}{*}{$\begin{array}{l}\text { Absolute difference } \\
\text { in labour regulation }\end{array}$} & -0.705 & -0.726 & -0.573 & -0.501 \\
\hline & $(6.24)^{* *}$ & $(6.51)^{* *}$ & $(3.64)^{* *}$ & $(3.08) * *$ \\
\hline \multirow{2}{*}{$\begin{array}{l}\text { Total number of } \\
\text { industries, state } r\end{array}$} & 0.551 & 0.564 & 0.423 & 0.512 \\
\hline & $(53.39)^{* *}$ & $(53.33)^{* *}$ & $(14.67)^{* *}$ & $(10.66)^{* *}$ \\
\hline \multirow{2}{*}{$\begin{array}{l}\text { Total number of } \\
\text { industries, state } \mathrm{s}\end{array}$} & 0.677 & 0.684 & 0.623 & 0.661 \\
\hline & $(105.27)^{* *}$ & $(106.94)^{* *}$ & $(20.01)^{* *}$ & $(19.93)^{* *}$ \\
\hline \multirow[t]{2}{*}{ Constant } & -43.682 & -46.629 & -22.983 & -39.991 \\
\hline & $(42.91)^{* *}$ & $(34.91)^{* *}$ & $(8.65) * *$ & $(5.24)^{* *}$ \\
\hline State dummies & No & No & Yes & Yes \\
\hline Year dummies & No & Yes & No & Yes \\
\hline Observations & 2160 & 2160 & 2160 & 2160 \\
\hline R-squared & 0.92 & 0.93 & 0.95 & 0.95 \\
\hline
\end{tabular}

Notes: Robust $t$ statistics in parentheses. $*$ significant at $5 \%$; ** significant at $1 \%$. 